\title{
Kemampuan Literasi Matematika Siswa SD Melalui Metode Team quiz berbantuan Media Konkret ditinjau dari Kemampuan Awal Matematika
}

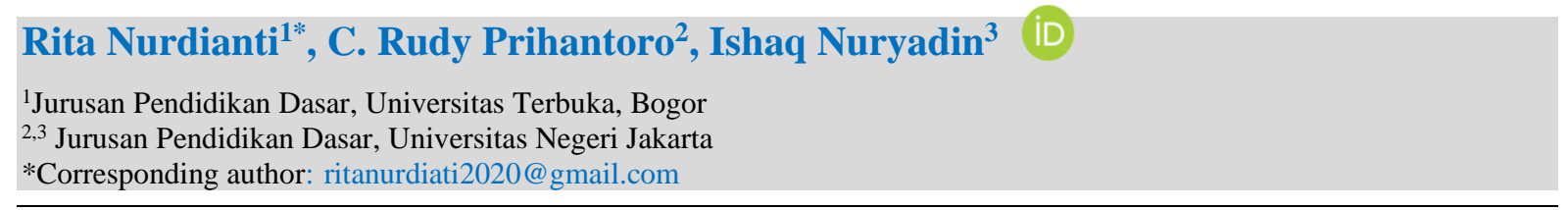

\section{Abstrak}

Matematika merupakan salah satu mata pelajaran yang dianggap sulit oleh siswa. Hal tersebut terjadi karena kurangnya pemahaman siswa terhadap konsep-konsep matematika. Kemampuan-kemampuan yang mendasari literasi matematis masih rendah dikuasai oleh siswa. Tujuan penelitian ini untuk menganalisis metode Team quiz dengan media konkrit dan kemampuan awal matematika terhadap kemampuan literasi matematik siswa SD. Jenis penelitian ini merupakan jenis quasi eksperimen. Desain penelitian yang dilakukan adalah treatment by level. Teknik pengambilan sampel untuk responden dilakukan teknik probability sampling probability sampling dengan jenis sample random sampling sebanyak dua kelas yaitu kelas IVA dan kelas IV B SD sebanyak 64 orang. Data penelitian dikumpulkan dengan menggunakan tes literasi matematik soal essay. Analisis data dengan menggunakan ANOVA dua jalur. Berdasarkan hasil analisis data, ditemukan hasil-hasil kemampuan literasi matematik siswa menggunakan metode Team quiz dengan media konkrit berbeda dengan kemampuan literasi matematik siswa yang menggunakan metode pembelajaran ekspositori. Kemampuan literasi matematik siswa yang memiliki kemampuan awal matematika tinggi berbeda dengan siswa yang memiliki kemampuan awal matematika rendah. Maka, metode team quiz berbantuan media konkret ditinjau dari kemampuan awal matematika.

Kata kunci: Team quiz, konkrit, literasi matematik

\section{Abstract}

The purpose of this study is to analyze: the influence of Team quiz method with concrete media and early mathematical ability on the mathematical literacy skills of elementary school students. Sampling techniques for respondents were conducted probability sampling probability sampling techniques with a type of random sampling sample as many as two classes, namely IVA class and grade IV B SDN Cibeureum as many as 64 people. This type of research uses quasi experiments with factorial research design of $2 \times 2$. The research data was collected using mathematical literacy tests on essays. Analyze the data using a two-lane ANOVA. Based on the results of the data analysis, the results of the study were found as follows(1) students' mathematical literacy skills using Team quiz method with concrete media are different from students' mathematical literacy skills using expository learning methods; (2) student mathematical literacy using Team quiz. method with concrete media is higher than student mathematical literacy using expository learning method; (3) the mathematical literacy ability of students who have high math early skills is different from those with low initial math skills; (3) there is an influence of interaction between Team quiz method and concrete media and mathematics initial ability on students' mathematical literacy skills; (4) students' mathematical literacy skills at the initial ability of high mathematics using team quiz method with concrete media higher than students' mathematical literacy skills using expository learning. (5) students' mathematical literacy skills at low initial mathematical ability using Team quiz method with higher concrete mediaAbstrak versi Bahasa Inggris ditulis menggunakan Bahasa Inggris dalam bentuk past tense dan kalimat yang berpatutan. Hasil dan kesimpulan ditulis dalam bentuk present tense. Abstrak diharapkan lebih komunikatif dan tidak monoton.

Keywords: Team quiz, concrete, mathematical literacy

\section{INTRODUCTION}

Matematika diartikan sebagai ilmu tentang bilangan, hubungan antara bilangan, dan prosedur bilangan operasional yang digunakan dalam penyelesaian masalah mengenai bilangan (Buyung \& Nirawati, 2018b; Chasanah et al., 2020). Tujuan pembelajaran matematika yaitu untuk melatih dan menumbuhkan cara berfikir secara sistematis, logis, kritis, kreatif dan konsinten, serta mengembangkan sikap gigih dan percaya diri dalam

$\begin{array}{ll}\text { History: } & \\ \text { Received } & \text { : October 02, } 2021 \\ \text { Revised } & \text { : October 06, 2021 } \\ \text { Accepted } & \text { : November 10, } 2021 \\ \text { Published } & \text { : November 25, } 2021\end{array}$


menyelesaikan masalah (Crismono, 2017; Lestari \& Putra, 2020). Pendidikan matematika pada hakekatnya mempunyai dua arah pengembangan yaitu untuk memenuhi kebutuhan masa kini dan masa dating (Buyung \& Nirawati, 2018a; I. ketut Suastika \& Rahmawati, 2019; Sumantri \& Pratiwi, 2015). Pelajaran matematika mempunyai peran penting untuk setiap individu karena dengan matematika setiap individu dapat meningkatkan kemampuan bernalar, berpikir kritis, logis, sistematis dan kreatif (Jeheman et al., 2019; Setiyani et al., 2020; Utami et al., 2018). Sehingga matematika selalu ada pada setiap jenjang pendidikan mulai dari sekolah dasar, menengah pertama, menengah atas dan sampai pada perguruan tinggi. Literasi matematis sebagai literasi matematik adalah kemampuan siswa untuk merumuskan, menggunakan dan menginterpretasi matematika dalam berbagai konteks (Ginanjar \& Akmal, 2020; Kusuma et al., 2017). Hal ini mencakup penalaran matematika dan menggunakan konsep, prosedur, fakta dan alat matematis untuk menggambarkan, menjelaskan dan memprediksi fenomena (Gunur et al., 2018; I. K. Suastika \& Amaylyla, 2019). Hal ini membantu seseorang dalam mengenal peran matematika dalam kehidupan dan membuat penilaian dan keputusan secara rasional dan logis yang dibutuhkan oleh warga negara yang konstruktif, terlibat aktif dan reflektif

Namun pada kenyataannya sedikit sekali orang yang menyukai matematika. Matematika merupakan salah satu mata pelajaran yang dianggap sulit oleh siswa (Firdaus et al., 2019; Rufaidah, 2019; Wahyuni et al., 2015). Kebanyakan siswa mengalami kesulitan dalam mengaplikasikan matematika ke dalam situasi kehidupan nyata (Khaerunnnisa \& Pamungkas, 2018; Purnama et al., 2020). Siswa cenderung hanya menghapalkan sejumlah rumus, perhitungan dan langkah-langkah penyelesaian soal yang telah dikerjakan guru atau yang ada dalam buku teks (Buyung \& Nirawati, 2018b; Indriani, 2018). Menurut data hasil survei Programme for International Student Assessment (PISA), peringkat Indonesia untuk matematika hanya menduduki 70 dari 72 negara peserta pada rata-rata skor 403, padahal ratarata skor internasional adalah 493. Rata-rata skor 403 menunjukkan bahwa kemampuan matematis siswa Indonesia terletak pada level terbawah (OECD, 2014). Berdasarkan hasil survey yaitu dengan penyebaran angket yang dilakukan di kelas IV sampai kelas VI mengenai mata pelajaran apa yang dianggap sulit ternyata $81 \%$ peserta didik menyatakan mata pelajaran matematika yang dianggap sulit. Hal tersebut terjadi karena kurangnya pemahaman siswa terhadap konsep-konsep matematika. Kemampuan-kemampuan yang mendasari literasi matematis masih rendah dikuasai oleh siswa, hal tersebut menjadi bahan refleksi bagi proses pembelajaran matematika di kelas, terutama untuk melihat sejauh mana ketersediaan materi dalam sumber belajar yang tersedia di sekolah yaitu buku paket mata pelajaran matematika, guru sebagai tenaga pendidik membelajarkan siswa yang menjangkau cakupan literasi sehingga kemampuan literasi matematis siswa dapat meningkat. metode pembelajaran yang digunakan oleh guru adalah metode konvensional yaitu ceramah, tanya jawab, dan tugas. Metode pembelajaran ini lebih cenderung ke teacher centered dari pada student centered sehingga masih terpaku pada guru. Metode pembelajaran ini waktu yang ada kurang dimanfaatkan untuk keaktifan belajar, tetapi hanya mendengarkan dan mencatat materi yang dibicarakan oleh guru. Hal ini menyebabkan guru sebagai pemeran yang dominan dalam proses belajar dan mengajar. Metode pembelajaran dengan ceramah pada pelajaran matematika belum mampu menarik perhatian dan memotivasi siswa untuk aktif dalam pembelajaran. Suasana belajar monoton dan kurang menyenangkan, sehingga siswa kurang aktif dan tidak bersemangat. Hal tersebut yang membuat siswa semakin manganggap matematika itu menyulitkan dan membosankan. Permasalahan tersebut jika dibiarkan akan memberikan dampak terhadap pendidikan.

Solusi yang dapat dilakukan untuk mengatasi permasalahan tersebut yaitu dengan menggunakan model atau metode pembelajaran yang inovatif. Metode Team quiz merupakan salah satu pembelajaran inovatif yang menuntut siswa bekerja sama dengan temannya untuk 
memecahkan masalah yang disajikan oleh guru (Parnayathi, 2020; Putri, 2020). Team quiz merupakan metode untuk melatih siswa belajar dan berdiskusi kelompok (Nurbani \& Sofyan, 2015; Parnayathi, 2020). Pelaksanaan pembelajaran menggunakan metode team quiz satu kelompok presentasi sedangkan kelompok lain diberikan kuis (Ernawati, 2019; Putri, 2020). Apabila kelompok tersebut tidak mampu menjawab maka pertanyaan dilempar ke kelompok lain dan seterusnya, sampai semua kelompok melakukan presentasi kemudian memberikan kuis (Nurdiansyah et al., 2021; Raisal \& Suwondo, 2018). Model ini menyajikan suatu kondisi belajar siswa aktif serta melibatkan siswa dalam suatu pemecahan masalah melalui tahap-tahap metode ilmiah (Ernawati, 2019; Nurbani \& Sofyan, 2015). Metode Team quiz yang diterapkan diharapkan siswa dapat mempelajari pengetahuan yang berhubungan dengan masalah yang disajikan serta dapat terampil dalam memecahkan masalah. Selain itu, model pembelajaran akan lebih efektif dengan menggunakan media pembelajaran konkret (Indriyani et al., 2019; Purnama Dewi, 2018). Media pembelajaran konkret dapat membantu siswa dalam memahami materi yang bersifat abstrak. Dengan media konkret pembelajaran akan lebih bermakna (Hadiyati \& Wijayanti, 2017; Kurniawati \& Nita, 2018).

Temuan penelitian sebelumnya menyatakan metode team quiz dapat meningkatkan hasil belajar (Parnayathi, 2020; Putri, 2020). Metode team quiz dapat meningkatkan motivasi belajar siswa (Putri, 2020). Dengan menerapkan metode team quiz dapat meningkatkan partisipasi siswa menjadi aktif (Nurbani \& Sofyan, 2015; Raisal \& Suwondo, 2018). Keterampilan literasi sangat penting untuk dimiliki oleh siswa (Chasanah et al., 2020; Kusuma et al., 2017). Kemampuan literasi matematik siswa yang menggunakan metode Team quiz dengan media konkrit lebih tinggi dibanding dengan kemampuan literasi matematik siswa yang menggunakan pembelajaran ekspositori. Penelitian ini bertujuan untuk menganalisis kemampuan literasi matematika siswa SD melalui metode team quiz berbantuan media konkret ditinjau dari kemampuan awal matematika. Adanya penelitian ini diharapkan dapat meningkatkan kemampuan literasi matematik antara siswa menggunakan metode Team quiz dengan media konkrit.

\section{MATERIALS AND METHODS}

Penelitian menggunakan metode kuantitatif jenis quasi eksperimen. Desain penelitian yang dilakukan adalah treatment by level atau desain faktorial $2 \times 2$ atau desain kelompok kontrol pretest dan postest. Sampel terdiri dari dua kelas yaitu kelas eksperimen dan kelas kontrol. Pada kelas eksperimen siswa menggunakan pembelajaran Team quiz dengan media konkrit, sedangkan pada kelas kontrol siswa belajar mata pelajaran matematika menggunakan model pembelajaran ekspositori. Selanjutnya, kedua kelas ini juga diuji tingkat kemampuan awal matematika yang dimiliki oleh setiap siswa dengan tujuan mengidentifikasi kelompok siswa yang memiliki kemampuan awal matematika tinggi dan siswa yang memiliki kemampuan awal matematika rendah yang diidentifikasi sebagai variabel atribut. Sedangkan dalam variabel terikatnya adalah kemampuan literasi matematik. Subyek penelitian yang dijadikan sebagai populasi dalam penelitian ini adalah siswa sekolah dasar di Kabupaten Cianjur yang tersebar di 32 kecamatan. Populasi siswa berjumlah 426.314, yang terdiri dari siswa laki-laki 221.656 orang dan siswa perempuan 204.658 orang. Selanjutnya setelah pengambilan sampel, diperoleh sampel yang ditetapkan dalam penelitian ini yaitu siswa kelas IVA dan kelas IV B SDN Cibeureum Kecamatan Cugenang yang jumlahnya sebanyak 64 orang, yang terdiri dari 32 siswa kelas IVA dan 32 siswa kelas IVB. Instrumen yang digunakan dalam penelitian ini berupa instrumen tes literasi matematik dan kuisioner/angket. Instrumen tes digunakan untuk mengetahui kemampuan literasi matematik siswa. Sedangkan instrumen kuesioner/angket digunakan untuk mengetahui pendapat atau tanggapan siswa mengenai metode pembelajaran Team quiz dengan media konkrit selama pembelajaran. Hasil 
uji validitas dan reliabilitas diperoleh semua soal tes literasi matematik valid dan relaibel. Metode analisis data menggunakan Anova dua Jalur dengan uji prasyarat menggunakan uji normalitas dan homogenitas.

\section{RESULTS AND DISCUSSION}

\section{Results}

Data penelitian ini berupa data kuantitatif yang diperoleh melalui tes kemampuan literasi matematik dan pengisian angket/skala sikap siswa terhadap matematika selama pembelajaran berlangsung pada kelas yang menggunakan pendekatan metode Team quiz dengan media konkret dan kelas yang memperoleh pembelajaran ekspositori. Pengujian hipotesis pertama dilakukan dengan menggunakan uji Anova Dua Jalur, tetapi sebelumnya dilakukan uji persyaratan yaitu uji normalitas distribusi dan homogenitas varians populasi. Untuk menguji normalitas dilakukan dengan menggunakan uji Kolmogorov-Smirnov Z (K-S Z) dengan kriteria pengujian: jika nilai (sig.) lebih dari 0,05 maka data berdistribusi normal.. Berikut ini hasil uji Kolmogorov-Smirnov Test disajikan pada Tabel 1.

Tabel 1. Tabel Uji Normalitas Kemampuan Literasi Matematik Siswa

\begin{tabular}{lccc}
\hline \multirow{2}{*}{ Kelas } & \multicolumn{3}{c}{ Kolmogorov-Smirnov $^{\mathbf{a}}$} \\
\cline { 2 - 4 } & Statistik & df & Signifikan \\
\hline $\begin{array}{l}\text { Metode Teams Quiz dengan media } \\
\text { konkret }\end{array}$ & 0,162 & 25 & 0,088 \\
Ekspositori & 0,140 & 25 & 0,200 \\
\hline
\end{tabular}

Berdasarkan Tabel 1 dapat diambil kesimpulan bahwa sampel berdistribusi normal karena nilai probabilitas (sig.) lebih dari 0,05 artinya data postes literasi matematik siswa yang memperoleh pembelajaran Metode Team quiz dengan media konkret dan data siswa yang memperoleh ekspositori berdistribusi normal. Karena data berdistribusi normal, maka dilanjutkan dengan uji homogenitas. Pengujian homogenitas tersebut digunakan uji Levene. Kriteria pengujian uji Barlet yaitu jika nilai signifikan lebih dari 0,05; Berdasarkan hasil perhitungan uji Levene diperoleh nilai sig. 0,714 lebih dari 0,05 sehingga hasil perhitungan uji homogenitas varians kemampuan literasi matematik siswa menunjukkan bahwa varians dari kedua kelompok sampel adalah homogen. Selanjutnya dilakukan uji perbedaan sampel dengan menggunakan uji statistik Anova dua jalur. Berdasarkan hasil perhitungan uji statistik Anova dua jalur diperoleh pendekatan Team quiz dengan media konkret nilai probabilitas Fhitung sebesar 8,997 > Ftabel sebesar 3,41 atau dapat dilihat dari nilai signifikansi sebesar $0,000<0,05$; maka Ha diterima atau Ho ditolak, sehingga dapat disimpulkan bahwa terdapat perbedaan kemampuan literasi matematik antara siswa yang memperoleh pembelajaran Teams Quiz dengan media konkret dengan siswa yang memperoleh pembelajaran ekspositori. Nilai rata-rata perbedaan rata-rata kemampuan literasi matemtaik siswa yang memperoleh pembelajaran Team quiz dengan media konkret dengan siswa yang memperoleh pembelajaran ekspositori sebesar 26,75; artinya kemampuan literasi matematik siswa yang memperoleh pembelajaran Teams Quiz dengan media konkret lebih baik dari pada kemampuan literasi matematik siswa yang memperoleh pembelajaran ekspositori.

Untuk mengetahui perbedaan kemampuan literasi matematik kedua kelas berdasarkan kemampuan awal matematik kategori tinggi dan rendah dilakukan uji perbedaan dengan menggunakan uji statistik Anova Dua Jalur. Data kemampuan literasi matematik siswa yang berdasarkan kemampuan awal matematik tinggi dan rendah terlebih dahulu dilakukan perhitungan uji normalitas dan uji homogenitas. Uji normalitas distribusi data skor menggunakan uji Kolmogorov-Smirnov Z (K-S Z) dengan bantuan program SPSS 25. Jika 
data skor berdistribusi normal, maka dilanjutkan dengan uji homogenitas varians. Selanjutnya dilakukan uji perbedaan sampel dengan Anova Dua Jalur. Analisis Anova Dua Jalur dilakukan untuk mengetahui perbedaan kedua kelompok sampel berdasarkan kategori kemampuan awal matematika Tinggi, dan Rendah. Berdasarkan hasil perhitungan Uji Lanjut Tukey HSD Literasi Matematik diperoleh nilai sig sebesar 0,000 < 0,05 maka Ha diterima atau Ho ditolak artinya terdapat perbedaan kemampuan literasi matematik siswa yang memiliki kemampuan awal matematik tinggi dengan siswa yang memiliki kemampuan awal matematik rendah. Sehingga dapat disimpulkan bahwa terdapat perbedaan kemampuan literasi matematik siswa yang memiliki kemampuan awal matematika tinggi dengan siswa yang memiliki kemampuan awal matematika rendah. Untuk mengetahui pengaruh interaksi model pembelajaran yang digunakan dengan kemampuan awal matematika siswa terhadap kemampuan literasi matematik dilakukan uji statistik Anova Dua Jalur pada skor postes kemampuan literasi matematik siswa. Dari Hasil Uji Anova Dua Jalur dihasilkan bahwa sig pada baris kelas*KAM sebesar 0,000 > 0,05 artinya model pembelajaran dan kemampuan awal matematika mempengaruhi kemampuan literasi matematik siswa. Skor literasi matematik siswa pada KAM rendah di kelas eksperimen hampi sama dengan skor literasi matematik siswa pada KAM rendah di kelas kontrol, sedangkan skor literasi siswa pada KAM tinggi di kelas eksperimen berbeda jauh dengan skor literasi matematik pada KAM tinggi di kelas kontrol. skor literasi yang memiliki KAM tinggi di kelas eksperimen lebih tinggi daripada skor literasi siswa yang memiliki KAM itnggi pada kelas kontrol. hal itu dapat dilihat pada garis biru yang menunjukkan skor literasi matematik siswa yangn memiliki KAM tinggi pada kelas ekserimen. Untuk menganalisis Kemampuan Literasi Matematik siswa yang memiliki KAM Tinggi pada kedua kelas. Kemampuan literasi matematik siswa dikelompokan terlebih dahulu berdasarkan kemampuan awal matematika kategori tinggi. Dari hasil deskripsi statistik kemampuan literasi matematik pada KAM tinggi didapat bahwa siswa yang memiliki KAM Tinggi sebanyak 19 orang pada kelas eksperimen dan sebanyak 17 orang pada kelas kontrol. Rata-rata kemampuan literasi matematik siswa pada kelas eksperimen sebesar 87,47 dengan simpangan baku sebesar 7,99 sedangkan pada kelas kontrol sebesar 82,29 dengan simpangan baku sebesar 4,66. Nilai maksimum dan minimum pada kelas eksperimen sebesar 100,00 dan 75,00; sedangkan pada kelas kontrol sebesar 90,00 dan 76,00 .

Selanjutnya untuk mengetahui perbedaan kemampuan literasi matematika kedua kelas berdasarkan kemampuan awal matematika kategori tinggi dilakukan uji normalitas, homogenitas dan uji perbedaan rata-rata. Uji normalitas distribusi data skor menggunakan uji Kolmogorov-Smirnov Z (K-S Z). Berdasarkan hasil uji normalitas diperoleh data berdistribusi normal karena nilai probabilitas (sig.) $=0,083$ dan 0,200 lebih dari 0,05. Maka dapat dilanjutkan dengan melakukan uji homogenitas. Berdasarkan hasil perhitungan uji levene diperoleh nilai signifikan sebesar 0,817 lebih dari 0,05 sehingga hasil perhitungan uji homogenitas varians kemampuan literasi matematik siswa menunjukkan bahwa varians dari kedua kelompok sampel adalah homogen. Berdasarkan hasil uji Anova dua jalur diperoleh nilai sig. 0,00 kurang dari 0,05 maka Ho ditolak atau dapat diartikan bahwa terdapat perbedaan kemampuan literasi matematika siswa yang memperoleh Metode Team quiz dengan media konkret dengan siswa yang memperoleh pembelajaran ekspositori bagi siswa yang memiliki kemampuan awal matematika tinggi. Adapun deskripsi statistik kemampuan literasi matematik siswa berdasarkan kemampuan awal matematika rendah disajikan dalam Tabel 2. 
Tabel 2. Deskriptif Statistik pada KAM Rendah

\begin{tabular}{|c|c|c|c|c|c|c|}
\hline Literasi & $\mathbf{N}$ & Minimum & Maximum & Mean & Std.Deviation & Variance \\
\hline $\begin{array}{l}\text { Team quiz } \\
\text { dengan media } \\
\text { konkrit }\end{array}$ & 6 & 42.00 & 64.00 & 50.8333 & 8.63520 & 74.567 \\
\hline Ekspositori & 11 & 49.00 & 55.00 & 51.7273 & 2.00454 & 4.018 \\
\hline $\begin{array}{l}\text { Valid N } \\
\text { (listwise) }\end{array}$ & 6 & & & & & \\
\hline
\end{tabular}

Berdasarkan Tabel 2 diperoleh rata-rata kedua kelas hampir sama yaitu 90,86 untuk kelas eksperimen, dan 124,86 untuk kelas kontrol. Dari hasil deskripsi statistik kemampuan literasi matematik pada KAM rendah didapat bahwa siswa yang memiliki KAM rendah sebanyak 6 orang pada kelas eksperimen dan sebanyak 11 orang pada kelas kontrol. Rata-rata kemampuan literasi matematik siswa pada kelas eksperimen sebesar 50,83 dengan simpangan baku sebesar 8,64 sedangkan pada kelas kontrol sebesar 51,72 dengan simpangan baku sebesar 2,004. Nilai maksimum dan minimum pada kelas eksperimen sebesar 64,00 dan 42,00; sedangkan pada kelas kontrol sebesar 55,00 dan 59,00. Hal tersebut menunjukkan bahwa rata-rata skor siswa yang mendapat pembelajaran matematika dengan menggunakan Metode Teams Quiz dengan media konkret lebih kecil dari rata-rata skor literasi matematik pada pembelajaran ekspositori, berarti dapat dinyatakan rata-rata skor literasi siswa pada Metode Teams Quiz dengan media konkret berbeda dengan rata-rata skor literasi matematik siswa pada pembelajaran ekspositori. Berdasarkan uji normalitas dapat diambil kesimpulan bahwa sampel berdistribusi normal karena nilai probabilitas (sig.) lebih dari 0,05 untuk siswa yang memperoleh pembelajaran Metode Team quiz dengan media konkret dan siswa yang memperoleh pembelajaran ekspositori berdasarkan kategori kemampuan awal matematika rendah. Kemudian untuk menguji homogenitas tersebut digunakan uji Levene. Berdasarkan hasil perhitungan uji Levene diperoleh nilai signifikan sebesar 0,068 lebih dari 0,05 sehingga hasil perhitungan uji homogenitas varians kemampuan literasi matematik siswa menunjukkan bahwa varians dari kedua kelompok sampel adalah homogen diperoleh nilai sehingga hasil perhitungan uji homogenitas varians kemampuan literasi matematik siswa menunjukkan bahwa varians dari kedua kelompok sampel adalah homogen.

Berdasarkan hasil perhitungan deskripsi stisktik pada skor literasi matematika siswa yang memiliki KAM rendah diperoleh bahwa rata-rata kemampuan literasi matematik siswa yang menggunakan metode Team quiz dengan media konkrit lebih tinggi dibanding dengan kemampuan literasi matematik siswa yang menggunakan pembelajaran ekspositori, bagi siswa yang memiliki kemampuan awal matematika rendah. Nilai rata-rata kemampuan literasi matematik siswa yang memiliki KAM rendah diperoleh bahwa rata-rata literasi matematik siswa pada kelas yang menggunakan metode Team quiz dengan media konkrit sebesar 50,83 dan rata-rata literasi matematik sisqa pada kelas yang menggunakan metode ekspositori sebesar 51,72. Selain itu dapat dilihat pada nilai minimum skor literasi matematik Hal itu menunjukkan bahwa kemampuan literasi matematik siswa pada kelas ekspositori yang memeiliki KAM rendah tidak lebih tinggi daripada siswa pada kelas menggunakan metode Teams Quiz dengan media konkret. Sehingga, dapat disimpulkan bahwa kemampuan literasi matematik siswa yang memperoleh pembelajaran Teams Quiz dengan media konkret hamper sama dengan literasi matematik siswa yang memperoleh pembelajaran ekspositori berdasarkan kemampuan awal matematika rendah. Hasil tersebut memberikan gambaran bahwa Team quiz dengan media konkret dapat meningkatkan kemampuan literasi matematik pada siswa yang memiliki kemampuan awal rendah. Walaupun hasilnya belum optimal, karena masih minimnya rata-rata kemampuan akhir yang dapat dicapai pada kelas kesperimen yakni sebesar 50,83 sedangkan rata-rata postes kemampuan literasi matematik 
pada kelas kontrol sebesar 52,73. Maka dapat diartikan siswa yang memiliki kemampuan awal rendah lebih cocok dengan pembelajaran ekspositori.

\section{Discussion}

Temuan pertama, terdapat perbedaan kemampuan literasi matematik antara siswa yang memperoleh pembelajaran Teams Quiz dengan media konkret dengan siswa yang memperoleh pembelajaran ekspositori. Pada pembelajaran dengan menggunakan metode Team quiz dengan media konkret, siswa belajar dengan aktif dan antusias sehingga dapat menumbuhkan semangat yang tinggi. Siswa berusaha untuk memaham materi yang disajikan dalam bentuk masalah kontekstual, dengan begitu siswa mengalami proses belajar. Pada kelas kontrol dengan pembelajaran ekspositori, siswa belajar pasif karena siswa hanya menerima langsung materi dari guru dan hanya duduk manis saja mendengarkan penjelasana materi dari guru, setelah itu, siswa melakukan latihan soal. Siswa tidak mendapatkan pengalaman langsung melakukan pengamatan seperti pada kelas eksperimen. Kerucut pengalaman yang dikemukakan oleh Edgar Dale itu memberikan gambaran bahwa pengalaman belajar yang diperoleh siswa dapat melalui proses perbuatan atau mengalami sendiri apa yang dipelajari, proses mengamati, dan mendengarkan melalui media tertentu dan proses mendengarkan melalui bahasa. Semakin konkret media pembelajaran yang digunakan siswa dalam proses pembelajaran, contohnya pengalaman langsung mengoperasikan langsung dengan bantuan media konkret yang digunakan guru dalam pembelajaran, maka semakin banyak pengalaman yang diperolehnya. Sebaliknya semakin abstrak siswa memperoleh pengalaman, contohnya hanya mengandalkan bahasa verbal, maka semakin sedikit pengalaman yang akan diperoleh siswa. Hal ini menyebabkan kompetensi literasi matematik siswa pada kelas eksperimen lebih baik daripada siswa pada kelas kontrol. Belajar adalah suatu proses usaha yang dilakukan seseorang untuk memperoleh suatu perubahan tingkah laku yang baru secara keseluruhan, sebagai hasil pengalamannya sendiri dalam interaksi dengan lingkungannya (Fajriyah, 2018; Unaenah et al., 2020). Model pembelajaran dapat dijadikan pola pilihan, artinya para guru boleh memilih model pembelajaran yang sesuai, efektif, dan efisien untuk mencapai tujuan pembelajaran yang diharapkan (Nurbani \& Sofyan, 2015; Parnayathi, 2020).

Temuan kedua, terdapat perbedaan kemampuan literasi matematik siswa yang memiliki kemampuan awal matematik tinggi dengan siswa yang memiliki kemampuan awal matematik rendah. Selain itu, siswa yang berkemampuan awal tinggi, sehingga diskusi yang berlangsung di kelompok maupun di kelas berjalan efektif. Siswa yang berkemampuan awal tinggi dapat membantu siswa yang berkemampuan rendah. Kemampuan literasi matematik siswa dikelompokan terlebih dahulu berdasarkan kemampuan awal matematika kategori rendah. Kemampuan literasi matematik dapat membantu seseorang untuk memahami peran atau kegunaan matematika di dalam kehidupan sehari-hari sekaligus menggunakannya untuk membuat keputusankeputusan yang tepat sebagai warga negara yang membangun, peduli, dan berpikir (Prabawati, 2018). Kemampuan literasi matematis sangat penting karena sangat erat kaitannya dengan kehidupan sehari-hari (Muzaki \& Masjudin, 2019). Selama pembelajaran team quiz dengan media konkret pada umumnya, dalam setiap kali pertemuan siswa pada kategori kemampuan awal matematika rendah memerlukan bimbingan yang lebih besar dari pada peserta didik yang mempunyai kemampuan awal matematika tinggi. Hal ini tentunya mempengaruhi keaktifan siswa dalam dalam menyelesaikan masalah soal kemampuan literasi matematik.

Temuan ini diperkuat dengan penelitian sebelumnya yang menyatakan metode team quiz efektif digunakan pada proses pembelajaran untuk meningkatkan hasil belajar (Parnayathi, 2020; Putri, 2020). Metode team quiz dapat meningkatkan motivasi belajar siswa (Putri, 2020). Dengan menerapkan metode team quiz dapat meningkatkan partisipasi 
siswa menjadi aktif (Nurbani \& Sofyan, 2015; Raisal \& Suwondo, 2018). Keterampilan literasi sangat penting untuk dimiliki oleh siswa (Chasanah et al., 2020; Kusuma et al., 2017). Team quiz adalah teknik tim meningkatkan tanggung jawab murid atas materi yang sedang dipelajari dengan cara yang menyenangkan dan tidak mengancam (Nurdiansyah et al., 2021). Siswa akan merasa senang dan tidak takut karena dalam proses pembelajaran siswa menjadi sumber belajar bagi satu sama lain. Siswa yang memperoleh pembelajaran Team quiz dengan media konkrit, siswa mengerjakan permasalahan matematik dengan cara berkelompok dan saling bekerja sama sehingga memudahkan siswa dala memecahkan masalah matematika. Dalam proses pembelajaran ini siswa dituntut untuk lebih aktif belajar, bertanya dan menjawab dalam kelompok, guru akan memberikan tambahan ketika diperlukan pada pembelajaran yang dilakukan oleh siswa. Implikasi penelitian ini diharapkan dapat membantu mengembangkan kemampuan literasi matematik siswa.

\section{CONCLUSION}

Terdapat perbedaan kemampuan literasi matematik antara siswa menggunakan metode Team quiz dengan media konkrit dibandingkan kemampuan literasi matematik siswa yang menggunakan metode pembelajaran ekspositori pada siswa yang memiliki kemampuan awal matematika tinggi dengan siswa yang memiliki kemampuan awal matematika rendah, dan terdapat pengaruh interaksi antara metode Team quiz dengan media konkrit dan kemampuan awal matematika terhadap kemampuan literasi matematik siswa.

\section{REFERENCES}

Buyung, B., \& Nirawati, R. (2018a). Pengaruh Karakter Kerja Keras Terhadap Kemampuan Literasi Matematis Siswa Melalui Model Discovery Learning. JPMI (Jurnal Pendidikan Matematika Indonesia), 3(1), 21-25. https://doi.org/10.26737/jpmi.v3i1.519.

Buyung, \& Nirawati, R. (2018b). Pengaruh Karakter Kerja Keras Terhadap Kemampuan Literasi Matematis Siswa Melalui Model Discovery Learning. Jurnal Pendidikan Matematika Indonesia, 3(1), 21 - 25. https://doi.org/10.26737/jpmi.v3i1.519.

Chasanah, A. N., Wicaksono, A. B., Nurtsaniyah, S., \& Utami, R. N. (2020). Analisis Kemampuan Literasi Matematika Mahasiswa pada Mata Kuliah Statistika Inferensial Ditinjau dari Gaya Belajar. Edumatica: Jurnal Pendidikan Matematika, 10(2), 45-56. https://doi.org/10.22437/edumatica.v10i2.10621.

Crismono, P. C. (2017). Pengaruh Outdoor Learning Terhadap Kemampuan Berpikir Kritis Matematis Siswa The Influence Of Outdoor Learning On The Mathematical Critical Thinking Skills Of Students. Junal Pendidikan Matematika Dan Sains, 4(2), 106-113. http://journal.uny.ac.id/index.php/jpms Jurnal

Ernawati, E. (2019). Peningkatan Hasil Belajar Pai Dengan Metode Team Qiuz Siswa Kelas Vi. Jurnal Visi Ilmu Pendidikan, 29. https://doi.org/http://dx.doi.org/10.26418/jvip.v11i1.26014.

Fajriyah, E. (2018). Kemampuan Literasi Matematika Ditinjau dari Gaya Kognitif Siswa pada Model Double Loop Problem Solving Berpendekatan RME-PISA. Universitas Negeri Semarang.

Firdaus, A., Nisa, L. C., \& Nadhifah, N. (2019). Kemampuan Berpikir Kritis Siswa pada Materi Barisan dan Deret Berdasarkan Gaya Berpikir. Jurnal, 10(1), 68-77. https://doi.org/10.15294/kreano.v10i1.17822.

Ginanjar, A. Y., \& Akmal, R. (2020). Efektivitas Lembar Kerja Untuk Meningkatkan Kemampuan Literasi Matematika Mahasiswa PGSD. Jurnal Basicedu, 5(1), 239 - 
246. https://doi.org/10.31004/basicedu.v5i1.655.

Gunur, B., Makur, A. P., \& Ramda, A. H. (2018). Hubungan Antara Kemampuan Numerik Dengan Kemampuan Pemecahan Masalah Matematis Siswa Di Pedesaan. Jurnal $\begin{array}{llll}\text { Matematika Dan } & \text { 6embelajaran, } & 148-\end{array}$ https://doi.org/10.24252/mapan.2018v6n2a2.

Hadiyati, N., \& Wijayanti, A. (2017). Keefektifan Metode Eksperimen Berbantu Media Benda Konkret Terhadap Hasil Belajar IPA Siswa Kelas V Sekolah Dasar. JIPVA (Jurnal Pendidikan IPA Veteran), https://doi.org/https://doi.org/10.31331/jipva.v1i1.513.

Indriani, A. (2018). Penggunaan Blok Pecahan pada Materi Pecahan Sekolah Dasar. Jurnal Ilmiah Pendidikan Matematika, 3(1), 11-16. https://doi.org/10.26877/jipmat.v3i1.2418.

Indriyani, D., Mawardi, M., \& Wardani, K. W. (2019). Peningkatan Keterampilan Berpikir Kritis Melalui Model Inkuiri Berbantuan Media Konkret Pada Siswa Kelas 5 SD Negeri Mangunsari 05 Tahun Pelajaran 2018/2019. Jurnal Basicedu, 3(1). https://doi.org/https://doi.org/10.31004/basicedu.v3i1.74.

Jeheman, A. A., Gunur, B., \& Jelatu, S. (2019). Pengaruh Pendekatan Matematika Realistik terhadap Pemahaman Konsep Matematika Siswa. Mosharafa: Jurnal Pendidikan Matematika, 8(2), 191-202. https://doi.org/10.31980/mosharafa.v8i2.454.

Khaerunnnisa, E., \& Pamungkas, A. S. (2018). Pengembangan Instrumen Kecakapan Matematis Dalam Konteks Kearifan Lokal Budaya Banten Pada Materi Bangun Ruang Sisi Datar. Jurnal Matematika Kreatif-Inovatif, 9(1), 17 - 27. https://doi.org/10.15294/kreano.v9i1.11210.

Kurniawati, I. D., \& Nita, S.-. (2018). Media Pembelajaran Berbasis Multimedia Interaktif Untuk Meningkatkan Pemahaman Konsep Mahasiswa. DoubleClick: Journal of $\begin{array}{lllll}\text { Computer and Information } & \text { Technology, }\end{array}$ https://doi.org/10.25273/doubleclick.v1i2.1540.

Kusuma, B. J., Wardono, \& Winarti, E. R. (2017). Kemampuan Literasi Matematika Peserta Didik pada Pembelajaran Realistik Berbantuan Edmodo. UNNES Journal Of Mathematics Education, 5(3), 199 - 206. https://doi.org/10.15294/ujme.v5i3.12015.

Lestari, W. I., \& Putra, E. D. (2020). Efektivitas Pembelajaran Matematika Menggunakan Media Pemberian Tugas Google Form Di Masa Pandemi Covid-19 Terhadap Hasil Belajar Siswa. Laplace: Jurnal Pendidikan Matematika, 3(2), 129-141. https://doi.org/10.31537/laplace.v3i2.379.

Muzaki, A., \& Masjudin, M. (2019). Analisis Kemampuan Literasi Matematis Siswa. Mosharafa: Jurnal Pendidikan Matematika, 8(3), 493-502. https://doi.org/10.31980/mosharafa.v8i3.557.

Nurbani, \& Sofyan, H. (2015). Efektivitas metode pembelajaran quiz team pada matakuliah logika komputer ditinjau dari motivasi belajar mahasiswa. Jurnal Pendidikan Vokasi, 5(2), 261 - 272. https://doi.org/10.21831/jpv.v5i2.6424.

Nurdiansyah, N. M., Arief, A., Agustin, F. R., Hudriyah, H., Muassomah, M., \& Mustofa, S. (2021). Education Reconstruction: A Collaboration Of Quiz Team And Kahoot Methods In Learning Arabic. Komposisi: Jurnal Pendidikan Bahasa, Sastra, Dan Seni, 22(2), 93-106. https://doi.org/10.24036/komposisi.v22i2.111436.

OECD. (2014). PISA 2012 Results in Focus: What 15-year-olds know and 2 what they can do with what they know. OECD.

Parnayathi, I. G. A. S. (2020). Penggunaan Metode Pembelajaran Team Quiz sebagai Upaya Meningkatkan Prestasi Belajar IPA. Journal of Education Action Research, 4(4), 473-480. https://doi.org/10.23887/jear.v4i4.28642.

Prabawati, M. N. (2018). Analisis Kemampuan Literasi Matematik Mahasiswa Calon Guru 
Matematika. Mosharafa: Jurnal Pendidikan Matematika, 7(1), 113-120. https://doi.org/10.31980/mosharafa.v7i1.347.

Purnama Dewi, L. P. (2018). Penerapan Model Pembelajaran Quantum Teaching berbantuan Media Konkret untuk Meningkatkan Hasil Belajar IPA. Journal of Education Action Research, 2(1), 23. https://doi.org/10.23887/jear.v2i1.13727.

Purnama, S., Pitaloka, A., \& Maharani, I. P. (2020). The Effectiveness of Somatic , Auditory , Visualization, and Intellectually and Numbered Head Together Learning Models Against Students ' Mathematical Problem Solving Capabilities. Jurnal Matematika, 3(2), 175-182. https://doi.org/10.24042/djm.

Putri, D. P. (2020). Penggunaan Metode Pembelajaran Team Quiz Sebagai Upaya Meningkatkan Prestasi Belajar PKn. Journal of Education Action Research, 4(4), 452-458. https://doi.org/10.23887/jear.v4i4.28640.

Raisal, A. Y., \& Suwondo, N. (2018). Effectiveness Of Active Learning Method Quiz Team Type On Student Learning Outcomes In Subject Ohm Law In SMA Negeri 1 Pundong. Indonesian Review of Physics, 1(2), 33-36. https://doi.org/10.12928/irip.v1i2.716.

Rufaidah, R. (2019). Peningkatan Kemampuan Komunikasi Matematis Melalui Model Pembelajaran Kooperatif Tipe Think Talk Write (Ttw) Dengan Media Lkpd Pada Materi Relasi Dan Fungsi Siswa Kelas Viii-B Mts Al-Ma'Arif Bocek Karangploso Tahun Pelajaran 2017/2018. JPM: Jurnal Pendidikan Matematika, 4(2), 95. https://doi.org/10.33474/jpm.v4i2.2621.

Setiyani, S., Fitriyani, N., \& Sagita, L. (2020). Improving student's mathematical problem solving skills through Quizizz. JRAMathEdu (Journal of Research and Advances in Mathematics Education), 5(3), 276-288. https://doi.org/10.23917/jramathedu.v5i3.10696.

Suastika, I. K., \& Amaylyla. (2019). Pengembangan modul pembelajaran matematika dengan pendekatan kontekstual. Jurnal Pendidikan Matematika Indonesia, 4(2). https://doi.org/https://dx.doi.org/10.26737/jpmi.v4i2.1230.

Suastika, I. ketut, \& Rahmawati, A. (2019). Pengembangan Modul Pembelajaran Matematika Dengan Pendekatan Kontekstual. JPMI (Jurnal Pendidikan Matematika Indonesia), 4(2), 58. https://doi.org/10.26737/jpmi.v4i2.1230.

Sumantri, M. S., \& Pratiwi, N. (2015). The Effect of Learning Media and Types of Personality on Elementary Student's Mathematic Performance. American Journal of Educational Research, 3(3), 276-281. https://doi.org/10.12691/education-3-3-4.

Unaenah, E., Setyadi, arif rahman, Sari, putri widiya, El-Abida, S. F., Agustina, N., Fauziah, S., \& Leonardho, R. (2020). Pengembangan Aplikasi Pembelajaran Matematika Tentang Pengukuran Waktu, Panjang Dan Berat Untuk Sekolah Dasar. Jurnal Edukasi Dan Sains, 2(1), 192-201.

Utami, T. N., Jatmiko, A., \& Suherman. (2018). Pengembangan Modul Matematika dengan Pendekatan Science, Technology, Engineering, And Mathematics (STEM) pada Materi Segiempat. Jurnal Matematika, 1(2), 165-172. https://doi.org/10.24042/djm.v1i2.2388.

Wahyuni, S., Isnarto, \& Wuryanto. (2015). Pengembangan Karakter Kedisiplinan Dan Kemampuan Pemecahan Masalah Melalui Model Laps-Heuristik Materi Lingkaran Kelas-Viii. Unnes Journal of Mathematics Education, 4(2). https://doi.org/10.15294/ujme.v4i2.7594. 